\title{
Globalization, Religious Extremism and Security Challenges in the Twenty-First Century
}

\author{
Ogbonnaya, Ufiem Maurice \\ National Institute for Legislative Studies, National Assembly, Abuja, Nigeria
}

\begin{abstract}
Since the twentieth century, intensifying global transformations have led to the spread of religious extremism and jihadist movements. In the United States, there was the Al-Qaeda terrorist attack on the World Trade Centre on September 11, 2001 and similar attacks in Britain, Spain and other parts of Europe within the same period. Since 2011, sectarian clashes have lingered in northern Lebanon following the arrest of a Lebanese Islamist linked to the Syrian uprising. In Africa, the Boko Haram Islamic sect with known religious preferences and belief system has occasioned national security crisis in Nigeria. In Mali, the Tuareg fighters with support from Al-Qaeda have stoked a simmering rebellion in the country. All this has created global security challenges which threaten the security of nation-states and their citizens. This paper seeks to establish the nexus between globalization and the spread of religious extremism and how it poses a threat to global security.
\end{abstract}

Keywords: Globalization, religious extremism, international security, terrorism, political regimes

\section{Introduction}

Throughout history, people have perpetrated extreme violent acts in the name of religion - whether it be Christianity, Islam, Judaism, Hinduism or another faith. A complex series of psychological, political, historical and theological factors combine to trigger such behavior (Kressel, 2012).

Security threats occasioned by inter- and intrareligious crises are not twenty-first century phenomena. They date back to the periods far beyond the twenty-first century. For instance, the Crusades of the Middle Ages were an almost continuous series of military-religious expeditions made by European Christians in the hope of wresting the Holy Land from non-Christian Turks. For instance, between 1096 and nearly 1300, Crusaders, travelling in great armies, small bands or alone, journeyed into the Orient to wage war against the Moslems, who had become a serious threat to Christianity.

Also, the Thirty Years' War (1618-1648) which was a series of wars principally fought in Central Europe and involving most of the countries of Europe was fought largely on religious grounds. Though some scholars have argued that the origins, causes and goals of the conflict were complex and varied, and cannot be tied down to a single factor, the war was principally fought between Protestants and Catholics in the Holy Roman Empire. Till date, the war remains one of the longest and most destructive conflicts in European history, and one of the longest continuous wars in modern history. According to the Encyclopaedia Britannica (2008), its destructive campaigns and battles occurred over most of Europe, and by the time the war ended with the Treaty of Westphalia in 1648, the map of Europe had been irrevocably altered.

As isolated and remote as the case cited were compared to the global nature of religious crisis since the twentieth century, the crises no doubt, constituted threats to human existence and national security. During these periods, several human lives were lost, cities, empires and nation-states were devastated while national economies and stability were periled in monumental measures.

Since the twentieth century, intensifying global transformations have led to the spread of religious extremism and jihadist movements. In the United States, there was the Al-Qaeda terrorist attack on the World Trade Centre on September 11, 2001and similar attacks in Britain, Spain and other parts of Europe within the same period (Odock, 2006; Aydinli, 2006; Duru \& Ogbonnaya, 2010). Since 2011, sectarian clashes have lingered in northern Lebanon following the arrest of a Lebanese Islamist linked to the Syrian uprising (CNN, 3 June, 2012). In Africa, the Boko Haram Islamic sect with known religious preferences and belief has occasioned national security crisis in Nigeria (Eso, 2011; Onuoha, 2011). According to Onuoha, "the last decade in Nigeria has witnessed the resurgence of several Islamic sects seeking political and religious 
reforms in the country. These groups include, among others, the Islamic Movement of Nigeria, the Boko Haram (Nigerian Taliban), the Kala-Kato, the Darulislam, the Ahmadiya Movement, the Khadiriyyha, Darika Shi'a Salafiya (or Izala), the Tijjaniya, and the Tariqqa group. Of these sects, the activities of the Boko Haram remain one that is growing in scale and frequency. In Mali, the Tuareg fighters with support from Al-Qaeda in the Islamic Maghreb (AQIM) have stoked a simmering rebellion in the country. All this has created global security challenges which threaten the security of nation-states and their citizens. This paper engages in an analysis to establish the nexus between globalization and the spread of religious extremism and how it poses a threat to global security.

Structurally, the paper is divided into five sections. Section one is the introduction which serves as an overview of the issues under consideration. Section two reviews extant literature on the field and provides framework basic concepts used here. Section three considers how globalization serves as a force multiplier for religious extremism and insecurity. Section four suggests measures for tackling religious extremism and insecurity. Section four draws a conclusion on the discussion.

\section{Conceptual Framework and Literature Review}

\section{Conceptual Framework}

While security denotes a situation which provides national and international conditions favourable to the protection of a nation, state, and its citizens against existing and potential threats, national security traditionally is understood as "the acquisition, deployment and use of military force to achieve national goals" (Held and McGrew, 1998:226). In the contemporary political and scholarly discourse however, the concept of security cuts across many disciplines covering military protection, surveillance, protection of national values and human rights. According to Romm (1993), a nation is said to be secured when it does not have to sacrifice its legitimate interest to avoid war, and is able, if challenged, to maintain them by war. It has also been defined as the absence of threats to acquired values and the absence of fear that such values will be attacked. Implicitly therefore, national security is the ability of a nation to preserve its internal values from external threats (Romm, 1993). Extremism is any ideology or act (religious, political, socio-cultural or economic) perceived or claimed to violate common moral and acceptable standards, especially in politics. In other words, extremism refers to measures, acts or actions beyond what is considered as the norm or what is generally accepted as being normal. In contemporary political discourse however, the term extremism is almost invariably used pejoratively and most often associated with religious activities. But Kressel (2012) has noted that extremism in world history has not always been religious in origin as exemplified by the Red Army Faction of the 1970s, the fascism of the 1930s and the wave of anarchist attacks that plagued much of the Western world around the turn of the 20th century. The term may also sometimes be associated with person(s) who have different view(s) which is not consistent with the existing norm(s). However, it needs not necessarily imply that the person is a threat to the society or the government or any other agency. This is because as Kressel (2012) has argued, great good has also been carried out in the name of religious extremism across the globe though such good is not erased by the recognition that evil sometimes draws its inspiration from religious faith. Terrorism which is a dimension of insecurity is defined by the United States Law Code - the law that governs the entire country, to mean "premeditated, politically motivated violence perpetrated against non-combatant targets by sub-national groups or clandestine agents." Drawing from the same source, international terrorism refers to terrorism involving citizens or the territory of more than one country (U.S. Code Title 22, ch.38, para. 2656f(d). This is to say that international terrorism refers to those acts in which the terrorists cross national frontiers and carry out attacks, or attack foreign targets at home such as bombing embassies, or hijacking air or sea liners (Lesser, 1999:6).

Globalization is a typical social science concept, so easy to use but so difficult to define in such a way that it can ensure in-controvertible acceptance. It was in recognition of this fact that Clark (1997:6) asserts that 'the utility of 'globalization' as a theoretical concept is in dispute." Asobie (2001:37) agrees with Clark. According to him, "globalization is a contested concept. Its meaning is in contention. Its character is a point in dispute. Its history is mired in controversy". However, the "controversy" and "dispute" surrounding the definition and meaning of globalization arise from the fact that scholars and policy makers who write, do so from different disciplinary backgrounds as scholars and stand points as international actors.

Be that as it may, this paper asserts in line with Mittelman (2000:6) that globalization means a historical transformation in the economy of livelihoods and modes of existence; in politics, a loss in the degree of control exercised such that the locus of power gradually shifts in varying proportions 
above and below the territorial state; and in culture, a devaluation of a collectivity's achievements or perceptions of them. It can thus be concluded that globalization is a broad process permeating the whole world, with far - reaching ramifications covering economic, political and cultural dimensions of contemporary life (Ibrahim, 2002:2).

\section{Literature Review}

The concepts of security and insecurity are typical social science concepts that appear principally in the literature of social psychology, sociology, political science and allied subjects. In the framework of Political Science, the concept of security according to Bar-Tal \& Jacobson (1998) denotes a situation which provides national and international conditions favorable to the protection of a nation, state, and its citizens against existing and potential threats. The socio-psychological conceptual framework of security on the other hand, acknowledges the military, political, economic and cultural conditions which play an important role in creating situations of security. Specifically, however, the situation of security assures a survival of a state, its territorial integrity, repulsion of a military attack, defense and protection of citizens' life and property, protection of economic welfare and social stability (Haftendorn, 1991).

Analysts have examined the problem of insecurity generally from various perspectives. Cameron and McCormic (1954) have pointed out nine different sources of insecurity, namely; insecurity as emotional response to sudden external threats from within; and insecurity from a relatively constant threatening external situation; insecurity due to threat from within; and insecurity as a function of beliefs, especially religious; etc. These categories of insecurity are believed to be caused by "frustration and neurosis" (Cameron \& McCormic (1954:559). This classification notwithstanding, Cameron and McCormic's work contains little of what can be regarded as empirical research on insecurity. This is because the work is filled with speculations without empirical evidences. Also, issues raised are not exhaustively discussed.

Bar-Tal and Jacobson (1998) have also examined issues of security and insecurity. Using the security challenges in Israel as a case study, they specifically concerned themselves with approaches and methods of dealing with security situations. Thus, two main approaches to security studies were indentified, namely, political and socio-psychological approaches.

According to the political approach, security is an essential precondition of an ordered existence for an individual and societal system. Here, individuals and collectives must have a secured environment which allows them to pursue their goals without being subjected to threats. The argument of this approach is that, it is the role of the state to provide security to its citizens, both on internal and external levels. On the domestic level, the state has to create economic, societal, cultural, environmental, and educational conditions which assure life to its citizens. On the international level, the state has to defend the citizens against possible harm from external forces (Buzan, 1991). Thus, this approach is concerned with military alliances, and foreign policy. Comprehensive as this approach may be, it neglects the societal, cultural and psychological issues, especially religious issues, which are imperative to the study of security as experiences since the twentieth century has shown. The sociopsychological approach on the other hand, argues that people as individuals and/or as group members (e.g., members of social, cultural and economic groups, nations) experience security or insecurity, with regard to own personal life and/or with regard to their collective entity and its systems. Security thus, is a psychological experience. Generally, however, the paper did not explain, using both approaches to the study of security, what primarily causes insecurity in any given society.

In a recent study, Ellen Bal and Salemink (2010), examined security and insecurity from an anthropological perspective. Here, attempts were made to conceptualize insecurity from the perspective of social and human security. However, the major flaw of the paper is that it did not contextualize insecurity. In other words, the study did not locate insecurity within a given geographical environment or location.

\section{Globalization as Force Multiplier of Religious Extremism and Global Security Crisis}

A major feature in international relations since the twentieth century has been the increasing wave of globalization that has occasioned scientific and technological advancement in telecommunications (internet super highways); in transportation (supersonic air planes) and in military and strategic arsenals that know no national frontiers. The consequence of this increasing wave of globalization has been the transformation of our commonly held notions of space and time. Secondly, globalization has turned the whole planet earth into a "global village" such that every point on the planet is in constant and close touch with the rest of the world via electronic, satellite or telephone communication (Harvey, 1989; Giddens, 1990; Scholte, 1997; Odock, 
2006). Thus to understand the interplay between globalization and religious extremism and international security crisis, globalization must be understood as;

A dialectical phenomenon, in which events at one pole of a distanciated relation often produce divergent or even contrary occurrences at another. The dialectic of the local and global is a basic emphasis of the arguments employed here... (Giddens, 1991: 22). Or as Scholte (1997) has argued, globalization should be seen as a process whereby social relations ${ }^{1}$ acquire distanceless and borderless qualities, so that human lives are increasingly played out in the world as a single place.

This transformation of the world into a global village through the use of internet may well explain the escalation of the Jyllands- Posten Muhammad cartoons controversy otherwise referred to as Muhammad cartoons crisis. The crisis began after 12 editorial cartoons, most of which depicted the Islamic prophet Muhammad, were published in the Danish newspaper Jyllands- Posten on 30 September 2005. The newspaper announced that this publication was an attempt to contribute to the debate regarding criticism of Islam and self-censorship. Muslim groups in Denmark complained and the issue eventually led to protests, violent demonstrations and riots in many Islamic countries around the world including Nigeria (Henkel, 2010).

Secondly, the transformation of the world by the process of globalization also adequately explains the religious crisis that trailed the uploading of the movie, "Innocence of Muslims" an anti-Islamic movie trailer on YouTube in 2012. The 14-minute video clip on YouTube was perceived as denigrating the prophet Muhammad. This caused demonstrations and violent protests against the film to break out on September 11 in Egypt and spread to other Arab and Muslim nations including the 2012 Benghazi attack, and to some western countries. Fatwas were issued against the video's participants and a Pakistani Minister offered a bounty for the death of the producer Nakoula. By the time the protests stopped, hundreds of injuries and over 75 deaths were recorded including the US Ambassador to Libya, Christopher Stevens. The film has sparked debates about freedom of speech and internet censorship (Bridge, 2012a; 2012b; Zardari; 2012; Johnson; 2012).

Thirdly, the origin and escalation of the "Arab Spring" a pro-democracy uprising that swept through the Middle East and North Africa in 2010 and 2011 and saw the overthrow of political regimes in Tunisia, Egypt, Libya and Yemen have reasonably been attributed to the influence of the internet - a product of globalization. With particular reference to
Egypt, Sarihan (2012) has noted that the role of social media in the revolution was incredibly effective and important. Organizers communicated, directed, and encouraged people against Mubarak using Facebook, Twitter, Flicker, and other social media tools. Specifically, Sarihan stated that on April 6, 2008 a youth group emerged on Facebook as another movement against the Mubarak regime. The administrators of the Facebook group described themselves as youths from different backgrounds, ages, and social classes who did not have any political experience, but who were working together to change the current brutal regime to one of transparency, equality, and liberty. The April 6th group played an important role in helping to instigate the national rebellion. By January 22, 2011, the group had garnered over 380,000 members; making it the largest and the most active online group in Egypt (Saharin, 2012:71)

Fourthly, during the 2002 Miss World Beauty Pageant in Nigeria, bloody religious demonstrations and riots by Muslim fundamentalists in the Nigerian state of Kaduna claimed over 100 lives. The riots were triggered on November 20 when protesting Muslim youths burned down a newspaper office for a 'blasphemous' article which suggested that Prophet Mohammed would have liked to marry a Miss World beauty queen (The Straits Times, 22 November 2002).

The list is long and seemingly endless. But as analysts have argued, in identity terms, without the power of the internet and social media, Al Qaeda's efforts to project and position radical Islam as an alternative response to 'Western modernity' could not have been nearly as global in scope (TrzeciakDuval \& van Veen, 2012). The scenarios captured above may have informed the submission in 2006 by John Negroponte, then Director of U.S. National Intelligence when he wrote that;

The 21st century is less dangerous than the 20th century in certain respects, but more dangerous in others. Globalization, particularly of technologies that can be used to produce weapons of mass destruction (WMD), has led to the spread of jihadist movements, and of course, the horrific events of September 11, 2001 (Negroponte, 2006:1, 2).

Though all the cases cited above involved Islam, Kressel (2012) has argued that it would be obvious to anyone with a rudimentary exposure to world history that many other religious traditions, including, for example, Christianity, Hinduism and Judaism, have been associated with dangerous extremism. Such collective impulses have waxed and waned in various eras, and even today, there is no shortage of religious extremists outside of Islam. 
One of the major fallouts of the escalation of religious extremism is global security crisis. In most cases, religious extremists have metamorphosed into terrorist organizations resulting to violence and criminality as a means of influencing public policy. Williams (2008) has described them as Violent NonState Actors (VNSAs) and as at 2006, the United States Directorate of National Intelligence listed about 387 of such groups around the world (Negroponte, 2006). According to Williams (2008), an important factor in the understanding of the rise of Violent Non-State Actors (VNSAs) including religious extremism, since the events of September 11,2001 , is globalization. Williams submits that not only has globalization challenged individual state's capacity to manage economic affairs, it has also provided facilitators and force multipliers for VNSAs. According to him, global flow of arms, for example is no longer under the exclusive control of nation-states. Illicit arm dealers have become transnational players and have contributed to a diffusion of military power that has provided VNSAs with weapon capabilities that allow them to challenge government forces. In a similar vein, globalization has allowed Violent Non-State Actors to develop transnational social capital and to create alliance and generate support outside their immediate area of operations. Globalization, along with the rise of illicit global economy has also provided funding opportunities for Violent Non-State Actors and other terrorist groups generally.

Flowing from Williams (2008)' argument, it becomes obvious how globalization has aided the funding and coordination of Islamist fundamentalist and terrorist groups around the world. In Nigeria for instance, Boko Haram has links with other Islamic groups within and outside Africa. Its activities and operations are coordinated from Mali with funding and training from a number of sources including a United Kingdom-based Al-Muntada Trust Fund while its membership has spread to other West African countries such as Benin, Niger, Mauritania and up to Cameroun and Chad which also provide sanctuary for the group members (Nigerian Tribune, 2012; Okpaga, Ugwu and Eme, 2012). This has been made easy by the process of globalization.

As pointed out earlier, most religious extremist groups aim to influence government or public policies. In the process, they challenge the legitimacy of political regimes, sovereignty and territorial integrity of nation-states and threaten the security of states and their citizens. In Africa for instance, Boko Haram, Al-Qaeda in the Islamic Maghreb (AQIM), Tuareg rebels aided by several terrorist groups, among others seek to over throw legitimate governments in Nigeria, Algeria and Mali respectively to establish Islamic states (Walker, 2012; Dario and Riccardo, 2011; Thornberry and Levy, 2011). In Afghanistan and Pakistan, the hard-line Islamic Taliban movement has proved to be a formidable fighting force and a major threat to their governments. In statistical terms security crisis occasioned by religious extremism has left over a 100,000 persons dead around the world leaving behind misery, tears and sorrow. In Nigeria alone, the activities of Boko Haram have left over 6,000 persons dead. These include women and children that have done nothing to deserve such fate (Nigerian Crime News, May 31, 2011; USCIRF, March 20, 2012; Human Rights Watch, October, 2012).

\section{Tackling Religious Extremism and Insecurity: The Way Forward}

While it is taken for granted in the extant literature that religious extremism has in the recent past been propelled by the current form and dimension of globalization, more attention ought to be paid not on what propels it but on the fact that it not only represents a common challenge to national and international security, extremist groups have also, especially since the dawn of the twenty - first century, emerged powerful state security challengers that the state monopoly of the use of force is increasingly being reduced to a convenient fiction (Williams, 2008). This calls for urgent measures to curtail religious extremism and insecurity around the world. In this direction, we make the following submissions;

Some scholars and policy analysts have attributed religious extremism and its attendant insecurity to abject poverty and lack of education among adherents of many religions (Saeed, Rahid, Rehman, Mobin \& Ahmed, 2012). They argue that poverty not only causes extremism but that it also plays havoc in other scenarios such as the gruesome political and ethnic violence that are witnessed around the world on regular basis. Consequently, global agreements must be reached among states and their governments for cooperation in various areas in order to provide mass and qualitative education for their citizens, bridge socio-economic inequalities which in most cases result in aggressive behaviours among the less privileged and curtail international crime and terrorism and reduce global insecurity.

Also, global agreements must be reached among national governments for cooperation and collaboration in the areas of security, joint-border patrol, strengthening of common or integrated immigration services in order to control movements of humans, goods and services around the world. 
This will help curtail cross border crimes and international terrorism and reduce security threats and challenges. The urgency of this cooperation in security areas and issues is most prevalent in Africa and other Third World Countries where border security and immigration activities are porous and highly unregulated.

Finally, while we recognize the fundamental rights of the people to freedom of worship as enshrined in the 1948 Universal Declaration of Human Rights, we propose that in the twenty-first century, the idea of secular states should be revisited, reconsidered and reconstructed with a view to the state controlling, moderating and regulating the philosophical ideologies, doctrines and teachings of various religious faiths. Religious intolerance which results in extremism and violence breeds from the teachings of hate and intolerance being propagated by various religions. Thus, state's regulation and control of these teachings will curtail extremism and attendant insecurity.

\section{Conclusion}

The fore going analysis evidently explains the relationship between globalization and the escalation of religious extremism. Though the issue of religious extremism is not a twenty-first century phenomenon, its current form and dimension have been escalated by the process of globalization. Globalization has provided enabling environment for free movements of persons and information through internet super highways and other means. This has resulted in events in one part of the world having effects on what happens in other parts.

However, the worrisome fallout of religious extremism is that in extreme cases, it has constituted global security crisis threatening the sovereignty and territoriality of nation-states, the legitimacy of political regimes and the security of citizens.

To check further escalation of this development, global agreements must be reached among national governments for cooperation in order to bridge socioeconomic inequalities that results in aggressive behaviours among the less privileged while the idea of secular states should be reviewed to enable state to control, moderate and regulate the philosophical ideologies, doctrines and teachings of various religious faiths that instigate hatred and intolerance.

\section{Note}

1. Social relations here refer to countless and complex ways that people interact with and affect each other around the world.

\section{References}

Asobie, H.A. (2001). Globalization: A View from the South, Annals of the Social Science Academy of Nigeria, 13, 36-58

Aydinli, E. (2006), Globalization, Security and Non-State Actors. Paper presented to the GW Centre for the Study of Globalization. Retrieved from: http://gstudynet.org/ what/events/gweek/spring06/globalisation.php

Bar-Tal, D. \& Jacobson, D. (1998), Psychological Perspectives on Security, Applied Psychology, 47(1), 59- 71.

Bridge, R. (2012a). Citing Extremism, Russia Seeks to Ban 'Innocence of Muslims', RT News, September, 17, Retrieved from: http://rt.com/politics/russia-innocence-muslims-ban-film-335/

Bridge, R. (2012b). 'Our beloved Prophet is our Honor!': Thousands Rally in Pakistan against Anti-Islam Video, September 29, , RT News, September, 17, Retrieved from: http://rt.com/politics/russia-innocence-muslims-ban-film-335/

Buzan, B. (1991), New Patterns of Global Security in the TwentyFirst Century, International Affairs, Royal Institute of International Affairs.

Casale, D. (2008). EU Institutional and Legal Counter-terrorism Framework, Defence Against Terrorism Review, 1(1), 49 - 78,

Cameron, W. B. and McCormick, T. C. (1954), Concepts of Security and Insecurity, American Journal of Sociology, 59(6), 556-564.

Clark, I. C. (1997), Globalization and Fragmentation: International Relations in the Twentieth, Oxford: University Press

Dario, and Riccardo, (2011). Al Qaeda in the Islamic Maghreb (AQIM): Implications for Algeria's Regional and International Relations', Isituto Affari Internazionali, IAI, Working Papers 11/07, April

Duru, E. J. C \& Ogbonnaya, U. M. (2010), Globalization, International Terrorism and National Security Challenges. Kogi Journal of Politics, 1(1), 1 - 9.

Ellen, B., Salemink. O. and Eriksen, T. H. (2010), A World of Insecurity: Anthropological Perspectives on Human security, London: Pluto

Encyclopaedia Britannica, (2008). Thirty Years' War, Retrieved from: http://www. britannica.com/EBchecked/topic/592619/ Thirty-Years-War

Eso, H. (2011). Boko Haram: The Enemy Within. Retrieved from: www.kwenu.com/moe/2011/boko_haram_enemy_within. htm

Giddens, A. (1990), The Consequence of Modernity, Cambridge: Polity Press

Haftendorn, H. (1991). The Security Puzzle: Theory-Building and Discipline-Building in International Security, International Studies Quarterly, 35(1), 3-17.

Harvey, D. (1989). The Condition of Post-modernity, Oxford: Basil Blackwell

Held, D \& McGrew, A. (1998). The End of the Old Order?, Review of International Studies, No. 24, p. 219-243

Henkel, H. (2010). Fundamentally Danish? The Muhammad Cartoon Crisis as Transitional Drama, Human Architecture: Journal of the Sociology of Self-Knowledge, Viii, 2, Fall, 67-82

Human Rights Watch, (2012). Spiraling Violence: Boko Haram Attacks and Security Force Abuses in Nigeria. United States of America: Human Rights Watch, October, 2012.

Ibrahim, J. (2002). Notes on Globalization and the Marginalization of Africa, Council for the Development of Social Science Research in Africa (CODESRIA) Bulletin, 384,3-7.

Johnson, T. (2012). 'Issue Guide: Muslims Protest Depictions of Mohammed', Council on Foreign Relations, September 20, http://www.cfr.org/middle-east/issue-guide-muslims-protestdepictions-mohammed/p29061

Kressel, N.J. (2012). 'The Mind of the Religious Extremist', Global, Retrieved from: http://www.globalbriefing.org/2012/01/the-mind-of-the-religious-extremist/

Lesser, I. B. (1999), Countering the New Terrorism. Retrieved from: www.rand.org/publication. 
Mittelman, J. (2000). The Globalization Syndrome: Transformation and Resistance. Princeton: Princeton University Press.

Negroponte, J. D. (2006). Annual Threat Assessment of the Director of National Intelligence Presented to the United States of American Senate Committee on Intelligence, February 2.

Nigerian Tribune, (2012). February 12, 2012

Romm, J.J. (1993). Defining National Security: The Non-Military Aspect, Council of Foreign Relations Press, New York.

Odock, C.N. (2006). International Relations: Background, Trends and Perspectives', in Political Science: An Introductory Reader, eds. Celestine Oyom Bassey and Godfrey Okechukwu Ozumba, Calabar: Wusen Publishers, 307 - 341.

Okpaga, A, Ugwu Sam Chijioke, U. S \& Eme, O. I. (2012). Activities of Boko Haram and Insecurity Question in Nigeria, Arabian Journal of Business and Management Review (OMAN Chapter), 1 (9), 77 - 99.

Onuoha, F. C. (2011). Small Arms and Light Weapons Proliferation and Human Security in Nigeria", Conflict Trends (Issue 1), South Africa: African Centre for the Constructive Resolution of Disputes (ACCORD), pp. 50-56.

Saeed, F. Rahid, M. Rehman, H. Z. Mobin, S \& Ahmed, S. (2012). Tackling Terrorism in Pakistan, International Journal of Peace and Development Studies, 3(1),1-5,

Sarihan, A. (2012). Is the Arab Spring in the Third Wave of Democratization? The Case of Syria and Egypt, Turkish Journal of Politics, 3(1), 67-85.

Scholte, J.A. (1997). 'The Globalisation of World Politics'. In Smith, $S$ and Baylis, J. (Eds.), The Globalisation of World Politics: An Introduction, Oxford: Oxford University Press, , 211-244.
The Straits Times (2002). 100 Die in Nigerian Riot over Miss World Article, Yale Global, A Publication of Yale Center for the Study of Globalization, 22 November 2002 Retrieved from: http://yaleglobal.yale.edu/content/100-die-nigerianriot-over-miss-world-article

Thornberry, W. \& Levy, J. (2011). Al- Qeada in the Islamic Maghreb', Homeland Security \& Counterterrorism Program Transnational Threats Project, Case Study No. 4, Centre for Strategic and International Studies (CSIS)

Trzeciak-Duval, A. \& Van Veen, E. (2012). Globalization with a Twist: Stability, Volatility and Fragility All in One, International Journal of Security and Development, 1(1),8084

United States Commission on International Religious Freedom (USCIRF) Annual Report 2012 - Countries of Particular Concern: Nigeria, 20 March 2012. Retrieved from: http://www.unhcr.org/refworld/docid/4f71a675a.html

Walker, A. (2012). What Is Boko Haram? United States Institute of Peace Special, Report 308 June, 2012.

Williams, P. (2008), Violent Non-State Actors and National and International Security. International Relations and Security Network Series, Zurich: Swiss Institute of Technology. Retrieved from: http://se2.isn.ch/serviceengine/filecontent? serviceID.ISFPub\&field=8EEBA9FE-AA15-32FC9434A lng $=$ en

Zardari, A.A. (2012). 'Latest Protests Against Depictions of Muhammad', the Associated Press, September 23, Retrieved from: http://bigstory.ap.org/article/latest-protests-againstdepictions-muhammad 